\title{
Photometric Determination of Copper in Iron and Steel with Diethyldithiocarbamate
}

\author{
John L. Hague, Eric D. Brown, and Harry A. Bright
}

\begin{abstract}
A method is described for the direct photometric determination of copper in steel and iron. An 0.1- to 0.25-gram sample is dissolved in diluted nitric acid, and a sulfuric-phosphoric-perchloric acid mixture is added. The solution is evaporated to fumes of sulfuric acid, diluted, and the sodium salt of dimethylglyoxime or ethylenediaminetetraacetic acid added as a complexing reagent. The copper diethyldithiocarbamate complex is then formed, and extracted with butyl acetate. The butyl acetate extract is washed with diluted sulf uric acid, and the absorbancy of the copper complex is measured at 560 to 600 millimicrons. An accuracy of about 0.005 percent of copper or better is indicated for steels containing 0.05 to 0.25 percent of copper, and of about 0.001 percent of copper for steels containing less than 0.05 percent of copper.
\end{abstract}

\section{Introduction}

Due to the increasing use of alloyed steel-scrap during the last decade, many of the residual elements in irons and steels have accumulated to the point where control and specification analyses are frequently required. One of the residual elements that is not removed in the usual steel-making processes is copper. Umpire determinations of copper in steel are generally made by the sulfideoxide, sulfide-electrolytic, or the thiosulfate-iodide method $[1,10] .{ }^{1} \quad$ While these methods yield accurate values when properly used, they require considerable manipulative ability and time. Attention has therefore been directed to the development of rapid photometric procedures for this determination.

One of the reagents frequently used for the photometric determination of copper is sodium diethyldithiocarbamate [3], the absorbancy of the copper carbamate complex being measured directly or after extraction with an organic solvent. Whereas a number of elements react with this reagent $[4,5,9]$, most of these elements are either not present ordinarily in steel and iron, or suitable conditions can be chosen to reduce or eliminate their interferences. For example, Haddock and Evers [6] have shown that ferric iron does not react with diethyldithiocarbamate in ammoniacal citrate solution, and a number of procedures have been developed on this basis for the photometric determination of copper in ferrous metals $[8,12,13]$

The procedures described in this paper are the result of a study to adjust conditions so that a large variety of ferrous materials can be handled directly without filtrations or aliquoting operations, and at the same time to retain an accuracy acceptable for umpire analyses.

Perhaps the chief difficulty encountered in using this reagent in the determination of copper is the fact that nickel also reacts. The use of dimethylglyoxime [2] to complex nickel and cobalt is not completely satisfactory because the nickel glyoxime

Figures in brackets indicate the literature references at the end of this paper. is also partially extracted and must be separated previous to the extraction. During the course of the present work, it was found that washing the butyl acetate extract with a dilute sulfuric acid solution removed the nickel glyoxime and stabilized the copper carbamate color. This technique provided a satisfactory method for the analysis of alloys containing up to 4 percent of nickel. The ethylenediaminetetraacetate ion has been shown [11] to form a useful complex with nickel and is employed in the procedure for high-nickel alloys.

The essential operations in the new procedures reported are as follows:

The sample is dissolved in dilute nitric acid or a mixture of nitric and hydrochloric acids. A sulfuric-phosphoric-perchloric acid mixture is added and the solution evaporated to fumes of sulfuric acid. The use of the sulfuric-phosphoric acid mixture provides for the complete solution of tungsten tool-steels. The solution is diluted and, after the addition of citric acid, is made slightly ammoniacal. The sodium salt of dimethylglyoxime or ethylenediaminetetraacetic acid is added as a complexing reagent, and sodium diethyldithiocarbamate is added to form the copper complex. The copper complex is extracted with butyl acetate, and the butyl acetate extract washed with dilute sulfuric acid. The absorbancy of the copper diethyldithiocarbamate complex in the butyl acetate layer is measured at 560 to $600 \mathrm{~m} \mu$, and the amount of copper is read from a calibration curve or from a table. A single determination can be completed in approximately 30 minutes, and a set of eight determinations can be completed in about 2 hours.

\section{Apparatus}

Colorimeter. An Evelyn type of colorimeter, filters, voltage stabilizer, and galvanometer as manufactured by the Rubicon Co. were used for most of the quantitative measurements reported in this paper. Matched test tubes (22 by $175 \mathrm{~mm}$ ) were used as absorption cells. 


\section{Reagents}

Sulfuric-phosphoric-perchloric acid mixture for fuming. To $200 \mathrm{ml}$ of dilute sulfuric acid $(1+1),{ }^{2}$ add $100 \mathrm{ml}$ of water, $100 \mathrm{ml}$ of phosphoric acid $(85 \%)$, and $50 \mathrm{ml}$ of perchloric acid $(70 \%)$. Dilute to $500 \mathrm{ml}$ with water and mix thoroughly.

Citric acid solution (250 g/liter). Dissolve $125 \mathrm{~g}$ of citric acid in about $250 \mathrm{ml}$ of water, add $10 \mathrm{ml}$ of dilute sulfuric acid $(1+1)$, and dilute to $500 \mathrm{ml}$.

Sodium dimethylglyoxime solution (10g/liter). Dissolve $5 \mathrm{~g}$ of sodium dimethylglyoxime octahydrate in $500 \mathrm{ml}$ of water

Disodium ethylenediaminetetraacetate solution (40 $g /$ liter $)$. Dissolve $20 \mathrm{~g}$ of disodium ethylenediaminetetraacetate dihydrate ${ }^{3}$ in $400 \mathrm{ml}$ of water, and dilute to $500 \mathrm{ml}$

Butyl acetate. A technical grade low in alcohols is satisfactory. Some lots of butyl acetate contain copper, and it may be necessary to wash the butyl acetate with dilute sulfuric acid $(5+95)$ before use. The washed reagent may be dried over anhydrous sodium sulfate.

\section{Procedures}

Carbon and alloy steels containing less than 4 percent of nickel or cobalt. Transfer $0.100 \mathrm{~g}$ of the sample ${ }^{4}$ to a $125-\mathrm{ml}$ Erlenmeyer flask, add $10 \mathrm{ml}$ of dilute nitric acid $(1+3),{ }^{5}$ and heat until the sample dissolves. Add $10 \mathrm{ml}$ of the "fuming acid" mixture, boil until brown fumes have been expelled, evaporate to fumes, and fume vigorously to remove the perchloric acid. Cool, add $10 \mathrm{ml}$ of water, and boil to remove chlorine. Cool and add $10 \mathrm{ml}$ of water and $10 \mathrm{ml}$ of the citric acid solution. Neutralize to litmus with ammonium hydroxide, cooling if necessary, and add 2 to $3 \mathrm{ml}$ of ammonium hydroxide in excess.

Cool the solution to room temperature and transfer it to a $125-\mathrm{ml}$ separatory funnel. Wash the flask with two $5-\mathrm{ml}$ portions of water and transfer the washings to the funnel. Add $15 \mathrm{ml}$ of the dimethylglyoxime solution, shake for 10 to 15 seconds, add $10 \mathrm{ml}$ of sodium diethyldithiocarbamate solution, and shake again for 10 to 15 seconds. Pipet exactly $20 \mathrm{ml}$ of butyl acetate into the funnel, shake for 30 seconds, and cool in running water for about 2 to 3 minutes. Repeat the shaking for 15 seconds, cool, and allow the layers to separate.

Drain off completely the lower aqueous layer ${ }^{6}$ and discard it. Add $25 \mathrm{ml}$ of dilute sulfuric acid $(5+95)$ to the funnel, shake for 15 seconds, and cool in running water. Repeat the shaking, allow the layers to separate, then drain off the aqueous layer and discard it. Transfer the butyl acetate extract to a test tube and stopper the tube.

\footnotetext{
2 This denotes 1 volume of concentrated sulfuric acid, sp gr 1.84, diluted with 1 volume of water. Dilute nitric acid $(1+3)$ denotes 1 volume of nitric acid, sp volume of water. Dilute pitric acid $(1+3)$ denotes 1 volume of nitric acid, sp
gr 1.42 , diluted with 3 volumes of water. If no dilution is specified, the concentrated reagent is meant.

${ }^{3}$ An "analytical reagent" grade of this chemical is produced by the Bersworth Chemical Co., Framingham, Mass., under the trade name Di Sodium Versenate. ${ }^{4}$ A sample weighing $0.250 \mathrm{~g}$ can be used if the copper content is less than $0.05 \%$. 5 For high-chromium materials also add $2 \mathrm{ml}$ of hydrochloric acid. Troubleamounts of silicon can be eliminated by adding 1 or 2 drops $(0.05 \mathrm{ml})$ of hydrofluoric acid.

6 The aqueous layer must be completely drained, or the iron complex will decompose in the acid wash-solution and form an interfering color.
}

Transfer a portion of the butyl acetate extract to a 2-cm absorption tube or cell and measure the absorbancy, using a narrow-band filter centered between 560 to $600 \mathrm{~m} \mu$. Use either butyl acetate or the blank solution to set the zero. Determine the percentage of copper from a calibration curve or table prepared from data obtained from synthetic solutions containing known amounts of copper and carried through all steps of the procedure. Correct the value obtained for a reagent blank, if the blank solution is not used as the "zero" solution.

Nickel, nickel-chromium, or nickel-chromium-cobalt alloys. Transfer $0.100 \mathrm{~g}$ of the sample to a $125-\mathrm{ml}$ Erlenmeyer flask, add $10 \mathrm{ml}$ of dilute nitric acid $(1-+3)^{7}$ and heat until the sample dissolves. Add $10 \mathrm{ml}$ of the fuming acid mixture, evaporate to fumes ${ }^{8}$ and fume vigorously to remove all perchloric acid. Cool, add $10 \mathrm{ml}$ of water, and boil to remove chlorine. Cool and add $10 \mathrm{ml}$ of water and $10 \mathrm{ml}$ of citric acid solution. Neutralize to litmus with ammonium hydroxide ${ }^{9}$ cooling if necessary, and add 3 to $5 \mathrm{ml}$ in excess.

Add $15 \mathrm{ml}$ of the ethylenediaminetetraacetate solution to the warm test solution and cool to room temperature or lower. Transfer the solution to a $125-\mathrm{ml}$ separatory funnel. Wash the flask with two 5 -ml portions of water and transfer the washings to the funnel. Add $10 \mathrm{ml}$ of the carbamate solution and complete the determination as described above. Since the copper carbamate color is somewhat slow in extracting from the "versene"-complexed solution, the shaking periods should be somewhat longer, 30 to 60 seconds.

7 Most high-chromium alloys will dissolve in nitrie-hydrochloric acid mixtures. For these alloys use $5 \mathrm{ml}$ of aqua regia - a mixture of three parts of hydrochloric For these alloys use $5 \mathrm{ml}$ of
acid and 1 part of nitric acid. $\underset{8}{\text { acid and } 1 \text { part of nitric acid. }}$ nickel or cobalt salts precipitate at this point but will redissolve during

9 Approximately $15 \mathrm{ml}$ of ammonium hydroxide is required to neutralize the acid, and as much as $10 \mathrm{ml}$ in excess does no harm.

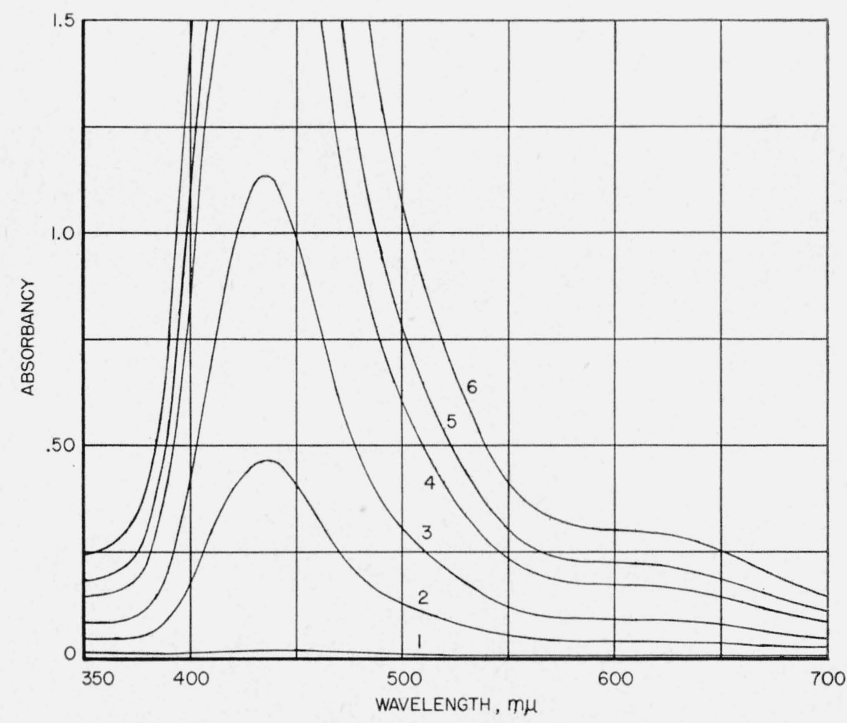

FIGURE 1. Curves showing absorption characteristics of copper diethyldithiocarbamate.

1, Blank; 2, 0.04-percent copper; 3, 0.10-percent copper; 4, 0.20-percent copper 5, 0.26-percent copper; 6, 0.36-percent copper. Cell length, $10.03 \mathrm{~mm}$. 


\section{Results and Discussion}

Calibration curves and tables were prepared in the usual manner [7] from data obtained by carrying known amounts of copper through all steps of the procedures and correcting to a zero absorbancy-zero concentration basis by appropriate blanks. The calibration curves obtained for the two procedures are identical within an experimental error of 1 to 2 percent and obey Beer's Law. Parallel experiments in the presence of iron (added as high-purity iron containing less than $0.0005 \%$ of copper) indicate that iron does not inhibit the extraction of the copper carbamate complex. The absorbing characteristics of the copper complex are shown in figure 1, which shows the absorbancy measurements obtained by John H. Gould with a Cary recording spectropho- tometer on one of the series of solutions used in calibrating the procedure.

The values obtained on a group of ferrous metals by the procedure for carbon and alloy steels low in nickel content $(<4 \%)$ are shown in table 1. As will be noticed, most of the average values are within 0.002 to 0.003 percent of the certificate value. A systematic trend toward values lower than the average certificate values is exhibited in the low-copper range. These lower values are probably due to the difficulties in the older procedures of completely separating copper from the other sulfide-forming elements, such as tin, arsenic, molybdenum, and the like, commonly present in ferrous materials and to the fact that rigorous blank corrections were run on all determinations.

Separate experiments on $0.25-$ and $0.50-\mathrm{g}$ samples

TABLE 1. Results obtained for copper by the procedure recommended for carbon and alloy steels $(<4 \% \mathrm{Ni})$

\begin{tabular}{|c|c|c|c|c|c|c|c|}
\hline \multirow{2}{*}{ NBS Standard sample } & \multicolumn{5}{|c|}{ Copper } & \multirow{2}{*}{$\begin{array}{l}\text { Weight of } \\
\text { sample }\end{array}$} & \multirow{2}{*}{ Type of steel } \\
\hline & $\begin{array}{l}\text { Certificate } \\
\text { value }\end{array}$ & Found & Difference & Range & $\begin{array}{l}\text { No. of de- } \\
\text { termina- } \\
\text { tions }\end{array}$ & & \\
\hline \multicolumn{8}{|c|}{ CARBON STEELS } \\
\hline $\begin{array}{l}9 \mathrm{~d} \\
8 \mathrm{f} \\
22 \mathrm{c} \\
8 \mathrm{~g} \\
129 \mathrm{a} \\
13 \mathrm{~d} \\
14 \mathrm{c} \\
10 \mathrm{e} \\
15 \mathrm{~d} \\
16 \mathrm{c} \\
51 \mathrm{a} \\
13 \mathrm{e} \\
11 \mathrm{e} \\
20 \mathrm{e} \\
19 \mathrm{e} \\
34 \mathrm{a} \\
35 \mathrm{a}\end{array}$ & $\begin{array}{c}\text { Percent } \\
0.009 \\
.009 \\
.011 \\
.019 \\
.021 \\
.022 \\
.025 \\
.032 \\
.040 \\
.054 \\
.060 \\
.082 \\
.103 \\
.105 \\
.111 \\
.166 \\
.222 \\
.267\end{array}$ & $\begin{array}{c}\text { Percent } \\
0.0053 \\
.0074 \\
\\
.0091 \\
\\
.0190 \\
.0184 \\
.0205 \\
.0236 \\
.0318 \\
.0394 \\
.052 \\
.061 \\
.082 \\
.098 \\
.105 \\
.109 \\
.166 \\
.222 \\
.262\end{array}$ & $\begin{array}{l}\text { Percent } \\
-0.0037 \\
-.0016 \\
-.0019 \\
\\
-.0026 \\
-.0015 \\
-.0014 \\
-.0002 \\
-.0006 \\
-.002 \\
+.001 \\
-.005 \\
-.002 \\
-. .- \\
-.005\end{array}$ & $\left\{\begin{array}{c}\text { Percent } \\
0.0052 \text { to } 0.0054 \\
0.0053 \\
0074 \text { to } \\
0.0074 \\
.0091 \text { to } .0075 \\
0.0090 \\
.0189 \text { to } .0190 \\
0.0192 \\
.0180 \text { to } .0186 \\
.0198 \text { to } .0212 \\
.0234 \text { to } .0237 \\
.0312 \text { to } .0322 \\
.0390 \text { to } .0404 \\
0.052 \\
.061 \text { to } .062 \\
0.082 \\
.097 \text { to } .100 \\
.104 \text { to } .107 \\
0.109 \\
.166 \text { to } .167 \\
.221 \text { to } .222 \\
.260 \text { to } .264\end{array}\right.$ & $\begin{array}{l}3 \\
1 \\
3 \\
1 \\
3 \\
1 \\
3 \\
3 \\
1 \\
3 \\
3 \\
3 \\
4 \\
4 \\
6 \\
3 \\
3 \\
3 \\
6 \\
6 \\
6 \\
3 \\
3 \\
3 \\
3\end{array}$ & $\begin{array}{l}g \\
0.500 \\
.250 \\
.500 \\
.250 \\
.500 \\
.250 \\
.500 \\
.250 \\
.250 \\
.250 \\
.250 \\
.250 \\
.250 \\
.100 \\
.100 \\
.100 \\
.100 \\
.100 \\
.100 \\
.100 \\
.100 \\
.100\end{array}$ & 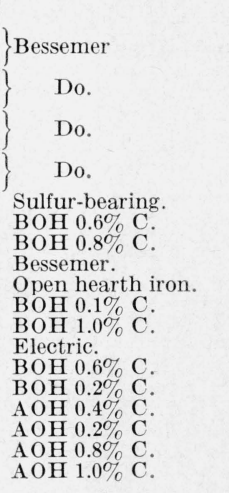 \\
\hline \multicolumn{8}{|c|}{ ALLOY STEELS } \\
\hline $\begin{array}{l}130 \\
133 \\
730 \mathrm{a} \\
153 \\
170 \\
50 \mathrm{~b} \\
132 \\
159\end{array}$ & $\begin{array}{r}0.017 \\
.061 \\
.080 \\
.092 \\
.099 \\
.102 \\
.110 \\
.149 \\
.181\end{array}$ & $\begin{array}{l}0.018 \\
.060 \\
.081 \\
.090 \\
.100 \\
.102 \\
.114 \\
.149 \\
.181\end{array}$ & $\begin{array}{r}+0.001 \\
-.001 \\
+.001 \\
-.002 \\
+.001 \\
+.004 \\
\end{array}$ & $\begin{array}{l}0.0174 \text { to } 0.0192 \\
.059 \text { to } .063 \\
.078 \text { to } .083 \\
.089 \text { to } .091 \\
.099 \text { to } .100 \\
.100 \text { to } .107 \\
0.114 \\
.148 \text { to } .150 \\
.179 \text { to } .181\end{array}$ & $\begin{array}{l}4 \\
4 \\
4 \\
4 \\
3 \\
6 \\
3 \\
3 \\
3 \\
3\end{array}$ & $\begin{array}{l}0.250 \\
.100 \\
.100 \\
.100 \\
.100 \\
.100 \\
.100 \\
.100 \\
.100\end{array}$ & $\begin{array}{l}\text { Lead-bearing } \\
14 \mathrm{Cr} ; 0.6 \mathrm{Mo} \\
14 \mathrm{Cr} \\
\mathrm{Cr}-\mathrm{V} \text { (SA E } 6135) \\
\text { Mo-W-Cr-V-Co } \\
\text { Titanium-bearing } \\
\text { W-Cr-V } \\
\text { Mo-W-Cr-V } \\
0.09 \mathrm{Ag}-1 \mathrm{Cr}\end{array}$ \\
\hline \multicolumn{8}{|c|}{ NICKEL STEELS } \\
\hline $\begin{array}{l}111 \mathrm{~b} \ldots \ldots \\
33 \mathrm{c} \ldots \\
111 \mathrm{a} \\
111 \\
101 \mathrm{c}\end{array}$ & $\begin{array}{l}0.028 \\
.031 \\
.079 \\
.122 \\
.124\end{array}$ & $\begin{array}{l}0.0248 \\
.026 \\
.0312 \\
.079 \\
.122 \\
.094 \\
.124\end{array}$ & $\begin{array}{c}-0.0032 \\
-.005 \\
+.0002 \\
-.030\end{array}$ & $\begin{array}{l}0.0222 \text { to } 0.0272 \\
0.026 \\
.0310 \text { to } .0313 \\
.078 \text { to } .079 \\
.115 \text { to } .127 \\
.085 \text { to } .102 \\
0.124\end{array}$ & $\begin{array}{l}9 \\
2 \\
3 \\
4 \\
3 \\
4 \\
2\end{array}$ & $\begin{array}{r}0.250 \\
.250 \\
.100 \\
.100 \\
.100 \\
.100 \\
.050\end{array}$ & $\begin{array}{l}1.75 \% \text { nickel } \\
3.28 \% \text { nickel } \\
1.75 \% \text { nickel } \\
1.75 \% \text { nickel } \\
9.0 \% \text { nickel }\end{array}$ \\
\hline \multicolumn{8}{|c|}{ CAST IRONS } \\
\hline $\begin{array}{l}122 \mathrm{~b} \\
107 \mathrm{a} \\
4 \mathrm{~g}\end{array}$ & $\begin{array}{r}0.047 \\
.105 \\
.240\end{array}$ & $\begin{array}{r}0.050 \\
.104 \\
.246\end{array}$ & $\begin{array}{r}+0.003 \\
-.001 \\
+.006\end{array}$ & $\begin{array}{l}0.0495 \text { to } 0.0504 \\
.103 \text { to } .106 \\
.241 \text { to } .250\end{array}$ & $\begin{array}{l}3 \\
3 \\
3\end{array}$ & $\begin{array}{r}0.100 \\
.100 \\
.100\end{array}$ & $\begin{array}{l}\text { Car-wheel } \\
\text { Nickel-molybdenum }\end{array}$ \\
\hline
\end{tabular}


TABLE 2. Results obtained for copper by the procedure recommended for materials high in nickel content

\begin{tabular}{|c|c|c|c|c|c|c|c|}
\hline \multirow{2}{*}{ NBS Standard sample } & \multicolumn{5}{|c|}{ Copper } & \multirow{2}{*}{$\begin{array}{c}\text { Weight of } \\
\text { sample }\end{array}$} & \multirow[b]{2}{*}{ Type of alloy } \\
\hline & $\begin{array}{c}\text { Certificate } \\
\text { value }\end{array}$ & Found & Difference & Range & $\begin{array}{l}\text { No. of } \\
\text { determi- } \\
\text { nations }\end{array}$ & & \\
\hline 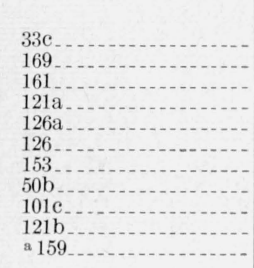 & $\begin{array}{c}\text { Percent } \\
0.031 \\
.04 \\
.085 \\
.092 \\
.097 \\
.099 \\
.110 \\
.124 \\
.124 \\
.181\end{array}$ & $\begin{array}{c}\text { Percent } \\
0.0297 \\
.013 \\
.040 \\
.086 \\
.088 \\
.094 \\
.098 \\
.114 \\
.120 \\
.126 \\
.186\end{array}$ & $\begin{array}{c}\text { Percent } \\
-0.0013 \\
+.001 \\
-.004 \\
-.003 \\
-.001 \\
+.004 \\
-.004 \\
+.002 \\
+.005\end{array}$ & $\begin{array}{c}\text { Percent } \\
0.0297 \text { to } 0.0300 \\
0.013 \\
.039 \text { to } .041 \\
.085 \text { to } .088 \\
.087 \text { to } .090 \\
.094 \text { to } .095 \\
.097 \text { to } .099 \\
.114 \text { to } .115 \\
.120 \text { to } .121 \\
.125 \text { to } .128 \\
.184 \text { to } .188\end{array}$ & $\begin{array}{l}4 \\
4 \\
4 \\
4 \\
4 \\
4 \\
4 \\
4 \\
4 \\
4 \\
4\end{array}$ & $\begin{array}{r}0.250 \\
.100 \\
.100 \\
.100 \\
.100 \\
.100 \\
.100 \\
.100 \\
.100 \\
.100 \\
.100\end{array}$ & $\begin{array}{l}3.3 \% \mathrm{Ni} \text { steel } \\
80 \mathrm{Ni}-20 \mathrm{Cr} \\
64 \mathrm{Ni}-17 \mathrm{Cr}-15 \mathrm{Fe} \\
11 \mathrm{Ni}-19 \mathrm{Cr}-0.4 \mathrm{Ti} \text { steel } \\
36 \mathrm{Ni} \text { steel } \\
36 \mathrm{Ni} \text { steel } \\
\mathrm{Mo}-\mathrm{W}-\mathrm{Cr}-\mathrm{V}-\mathrm{Co} \text { tool steel } \\
18 \mathrm{~W}-4 \mathrm{Cr}-1 \mathrm{~V} \text { steel } \\
18 \mathrm{Cr}-9 \mathrm{Ni} \text { steel } \\
18 \mathrm{Cr}-11 \mathrm{Ni}-0.4 \mathrm{Ti} \text { steel } \\
0.09 \mathrm{Ag}-1 \mathrm{Cr} \text { steel }\end{array}$ \\
\hline
\end{tabular}

a Extracts from this standard were slightly cloudy, presumably due to silver salts.

of high-purity iron indicated that amounts of copper up to 0.04 percent can be recovered in the presence of these quantities of iron to an accuracy of 0.0005 percent of copper. Blank corrections are very necessary, amounting to about 0.005 percent of copper on an $0.1-\mathrm{g}$ sample basis using regular analytical reagents without purification. This figure can be reduced to 0.001 percent or less if appropriate steps of purification are used. The "blank" has proved in practice to be quite reproducible for any one lot of reagents.

The failure of the dimethylglyoxime procedure in the presence of more than moderate amounts of nickel is indicated by the low values obtained on the higher weight samples of NBS Standard Samples 33c and $101 \mathrm{c}$, and is very likely caused by the occlusion or adsorption of the soluble copper gly oxime complex on the bulky nickel precipitate. Silver tends to give a cloudy extract, and the values reported for the silver-bearing steel, Standard Sample 159, are those obtained on centrifuged extracts, in order to eliminate this difficulty.

The results obtained by the procedure for ferrous materials high in nickel content are given in table 2 . As will be noticed, all of the average values are within 0.005 percent of the certificate value. Separate experiments run on copper alone, on copper and the ethylenediaminetetraacetate complex, and on copper, iron, and the complexing reagent indicate that these combinations in the concentrations specified do not materially affect the completion of the extraction of the copper carbamate. The reaction is a little slower in the presence of the ethylenediaminetetraacetate ion, and the time of shaking specified should not be shortened. Values given for the silver-bearing steel, Standard Sample 159, were obtained on extracts not centrifuged, and the high values reported are due to the slight turbidity of these extracts.

In all cases, the ammoniacal iron solution must be completely drained and separated from the butyl acetate extract, or the iron complexes will be partially decomposed and interfering colors will be extracted during the washing of the butyl acetate extract with the dilute sulfuric acid solution. While any possible difficulty could be taken care of by an intermediate ammoniacal citrate wash, the simpler procedure recommended has proved entirely satisfactory in practice.

Spectral curves showing the absorbing characteristics of extracts prepared from solutions containing nickel, cobalt, bismuth, lead, and silver are shown in figure 2. As will be seen, all of these elements, except silver, absorb least in the wavelength region recommended for measurement (560 to $600 \mathrm{~m} \mu$ ). The silver curve shows general absorption above $500 \mathrm{~m} \mu$, characteristic of turbid solutions. The nickel and cobalt interference is eliminated by the use of suitable complexing reagents. Interference from lead and silver in the amounts ordinarily present in steel is not serious, as is shown in table 1 . Bismuth is not ordinarily added as an alloying element in steel, but a few experiments made on synthetic mixtures with iron indicate that at least 1 percent of bismuth may be present without causing significant interference. Residual amounts of tin and small amounts of platinum, such as might be introduced by operations in platinum containers, also do not interfere.

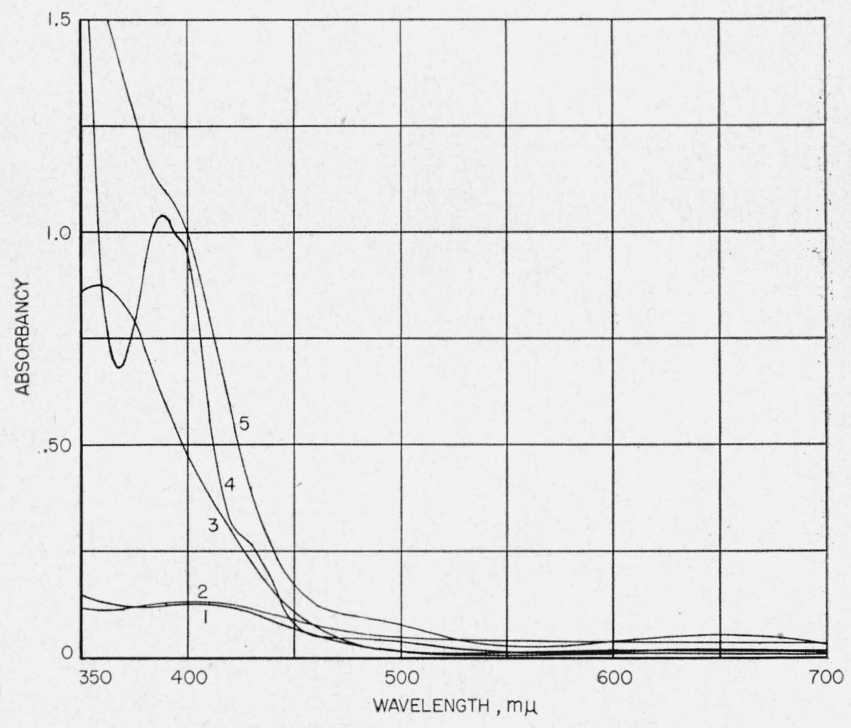

FiguRE 2. Curves showing regions of absorption.

1, Lead; 2, silver; 3 , bismuth; 4 , nickel; 5 , cobalt. 
Aside from the question of interferences, the absorbancy of the copper curves, figure 1, varies least with change in wavelength in the $600-\mathrm{m} \mu$ spectral region. This allows a filter photometer to be used in a routine manner under optimum conditions as regards requirements for spectral purity of the light used. As the high sensitivity of the copper reaction is also decreased, directly weighed samples of a practical size can be used, whereby the absolute amount of copper constituting the "blank" is reduced percentage-wise to a reasonable figure. This allows in everyday work the use of the usual quality of analytical reagents.

\section{References}

[1] ASTM Methods for chemical analysis of metals, Am. Soc. Testing Mat., pp. 97 to 100 (1950).
[2] L. I. Butler and H. O. Allen, J. Assoc. official Agr. Chem. 25, 569 (1942).

[3] T. Callan and J. A. R. Henderson, Analyst 54, 650 (1929).

[4] D. L. Drabkin, J. Assoc. official Agr. Chem. 22, 320 (1939).

[5] K. Gleu and R. Schwab, Angew. Chem. 62, 320 (1950).

[6] L. A. Haddock and N. Evers, Analyst 57, 495 (1932).

[7] J. L. Hague, ASTM Proceedings 44, 715 (1944).

[8] T. P. Hoar, Analyst 62, 788 (1937).

[9] R. J. Lacoste, M. H. Earing, and S. E. Wiberly, Anal. Chem. 23, 871 (1951).

[10] G. E. F. Lundell, J. I. Hoffman, and H. A. Bright, Chemical analysis of iron and steel, pp. 267 to 269 . (John Wiley and Sons, Inc., New York, N. Y., 1931).

111] V. Sedivec and V. Vasak, Collection Czechoslov. Chem. Comm. 15, 260 (1950).

[12] S. D. Steele and L. Russell, Analyst 74, 105 (1949).

[13] Arba Thomas, ASTM Proceedings 44, 769 (1944).

Washington, August 7, 1951. 